\section{Within School Walls: The Role of Discipline, Sexuality and the Curriculum}

\section{AnnMarie Wolpe}

Routledge: London, 1988, £9.95 Pbk ISBN 415008360

In 1984 Wood commented that the whole sexy atmosphere of the period of his research led him to reflect on the absence of any real work on sex as it manifests itself in schools. In this book AnnMarie Wolpe aims to show how disciplinary control and sexuality are central features of school organization, school experience and gender formation. The book is based on an ethnographic longitudinal study of the pupils and staff of one class, using methods of observation and interviews from 1972-4, 1976 and 1980. It explores how both femininity and masculinity are constructed through schooling by relating structural analysis of the labour market, the family and the popularization of ideologies with observational accounts of what actually happens in the classroom. The book aims to reposition the account of girls in terms of activity rather than passivity and, as such, contributes to research which emphasizes that females are not victims of male dominance. Wolpe argues that the popularization of feminist-interactionist accounts has led to the stereotyping that such analysis is at pains to dismiss. This challenge to patriarchal explanations whilst being an obvious strength of the book also results in certain weaknesses.

In the first section, Wolpe argues that the structure of disciplinary controls needs to be established before the pedagogic processes of the school, including gender differentiation, may be realized. Drawing from the work of Foucault, Wolpe distinguishes between disciplinary measures, the moral code of the school and the structure of knowledge within the school. These pro- cedures, she argues, are genderblind. In the book discipline is articulated as a discourse and an organizing principle, but in fact it tends to read as an open ideological category into which any power struggles and forms of control are inserted, without an analysis of how the subtleties of their operation are imbued with assumptions about gender, race and class.

Similarly, Wolpe claims that teachers were liked and able to maintain control of their pupils through their 'personalities' without reference to gender (p. 86, p. 142). Moreover, how race comes to inform definitions of and opposition to control is not explored. This is certainly somewhat different from the recent studies which see race and/or gender as categories for explicitly setting the boundaries for appropriate behaviour (for instance, McRobbie, 1978; Walkerdine, 1981; Wright, 1987; Frazer, 1988). Rather, Wolpe argues, it is notions of appropriate behaviour that contain gender. This semantic dilemma can be seen in the section on how teachers use sexual strategies as a means of control and how pupils rehearse sexual strategies as a means for testing out their sexuality and resisting control by the teachers. How can notions of gender be separated from strategies of discipline and control? This particular section is excellent for exposing the irony between official sex education which is located in health regulation, and the way sexuality is ubiquitous in classroom interaction. Through this Wolpe provides a much needed analysis of how control is achieved through gendered negotiations.

The section on the curriculum challenges the suggestions made by Willis that working-class boys choose to opt out of schooling through their identification with the hardness of manual labour. Rather, Wolpe suggests a process of negative default whereby it is the absence of knowledge about alternatives to their own positioning, as a result of 
their cultural heritage, that leads working-class pupils to reject school culture. This, however, fails to explain the differences between the black working-class pupils of this study and those identified by Fuller (1980) and Riley (1981) who succeed through schooling.

The study is important for putting on to the agenda areas that need further serious attention, such as: the use of sexual power in the classroom by both staff and pupils; masculinity in the form of noncelebration; the links between masculinity, performance and control; the inverted relationship between commitment to schooling and the emergent sexual awareness of girls; the lack of knowledge of both girls and boys as to future prospects after school; the fact that boys only pursue feminine subjects when their masculinity is secure; the future economic familial responsibility that informs boys' perceptions. Finally, identification of the appropriation of schooling by both girls and boys for 'having a laugh' suggests a characteristic of working-class culture, black and white, female and male, which operates right across different facets of social life.

\section{Beverley Skeggs}

\section{References}

DEEM, R. (1980) editor Schooling for Women's Work London: Routledge \& Kegan Paul.

FRAZER, E. (1988) 'Teenage Girls Talking About Class' Sociology, Vol. 22, No. 3, pp. 343-58.

FULLER, M. (1980) 'Black Girls in a London Comprehensive School' in DEEM (1980). McROBBIE, A. (1978) 'Working-Class Girls and the Culture of Femininity' in WOMEN'S STUDIES GROUP (1978), pp. 96-109.

RILEY, K. (1981) 'Black Girls Speak for Themselves' Multiracial Education Vol. 10, No. 10, pp. 3-12.

WALKERDINE, v. (1981) 'Sex, Power and Pedagogy' Screen Education No. 38, Spring, pp. 14-26.

WEINER, G. and ARNOT, M. (1987) editors Gender Under Scrutiny: New Inquiries in Education London: Hutchinson.

WOMEN'S STUDIES GROUP (1978) editors Women Take Issue London: Hutchinson.

WRIGHT, C. (1987) 'Relations Between Teachers and Afro-Caribbean Pupils: observing multiracial classrooms' in WEINER and ARNOT (1987) pp. 173-87.

\section{With Wings: An Anthology of Literature by Women With Disabilities}

Edited by Marsha Saxton and Florence Howe; British edition with a preface by Merry Cross

Virago: London, 1988, £4.95 Pbk

ISBN 0860681661

Literature can empower individuals and groups. There is now clearly a women's literature which celebrates women's creativity and lives, and fights against women's oppression. In doing so, it has an enduring impact on the culture which it seeks to change.

With Wings, an anthology of American women's writings, is a celebration of the literature of disabled women. It shouts out our talents, our concerns, with some wonderful pieces of work. In doing so, it claims both a place within the general culture and attempts to change that culture.

The anthology is divided into three sections of poems and prose. The first, 'Living in these bodies, these minds', gives voice to the physical realities of disability and illness. The introduction quotes Virginia Woolf: Considering how common illness is, how tremendous the spiritual change it brings, how astonishing, when the lights of health go down, the undiscovered countries that are then disclosed. . . . it becomes strange indeed that illness has not taken its place with love and battle and jealousy among the prime themes of literature'. To be disabled is not by any means necessarily to be ill, but the point is that 